\title{
Sığırlarda Ahır Zemin Tiplerinin Ayak Hastalıkları ve Tırnak Deformasyonları
}

\section{Üzerine Etkilerinin Araştırılması}

\author{
Mehmet Cengiz HAN, Aydın SAĞLIYAN, Eren POLAT*
}

Fırat Üniversitesi, Veteriner Fakültesi, Cerrahi Anabilim Dalı, Elazıı̆, Türkiye.

Geliș Tarihi: 24.10.2016

Kabul Tarihi: 24.11.2016

\begin{abstract}
Özet: Bu saha çalışmasında farkıı tipteki ahır zeminlerinin sığır ayak hastalıkları ve tırnak deformasyonları üzerine etkilerinin araştırılması amaçlandı. Araştırma Muş ve yöresinde rastgele seçilen 81 ahırda yürütüldü. Bu ahırlarda barındırılan farklı yaş, ırk, ağırlık ve cinsiyetteki toplam 1292 sığır materyal olarak kullanıldı. Bu ahırların zemin yapılarının tiplerine göre hayvanlarda görülen ayak hastalıkları ve tırnak deformasyonları oranları saptandı. Yapılan araştırmada elde edilen veriler ahır zemin tiplerinin sığır ayak hastalıkları ve tırnak deformiteleri üzerine önemli etkilerinin olduğu görülmüştür. İncelenen bu 81 ahırda beton zeminli barınaklarda \%32.97, taş zeminli barınaklarda \%8.51, tahta zeminli barınaklarda \%5.57, kauçuk zeminli barınaklarda \%6.66, toprak zeminli barınaklarda ise \%46.28 olarak ayak hastalıkları ve tırnak deformiteleri tespit edilmiştir. SPSS for Windows 21.0 (IBM) Descriptive Stastistics Analysis Crosstabs metoduyla Chi-Square testi kullanılarak, barınak zemin tiplerinin (beton, taş, tahta, kauçuk, toprak) yetiştirilen sığırların ayak hastalıkları ve tırnak deformasyonları üzerine olan etkilerinin araştırılması yönünden analizi yapıldı. Ulaşılan sonuçların ışığı altında $\mathrm{P}<0.05$ ve $\mathrm{P}<0.01$ aralıkları çalışma verileri açısından anlamlı olarak kabul edildi.
\end{abstract} Anahtar Kelimeler: Ayak Hastalıkları, Barınak zemini, Sığırlar.

\section{Investigation of Cattle in the Diseases of Stable Ground Foot Type and Nail on the Effects of}

\section{Deformation}

\begin{abstract}
This area of the barn floor in different types of work aimed to investigate the effects of foot diseases and nail deformation. Research, Mush and the region was carried out in 81 randomly selected in the barn. It is hosted in the stables of different ages, races, a total of 1292 cattle were used as material in weight and gender. This is based on the types of barn floor structure revealed foot diseases and nail deformation rates in animals. The data obtained in the studies has been shown to have a significant effect on the cattle disease foot and nail deformities of barn flooring types. Investigation of the 81 in the shelter, concrete floors in the barn \%32.97, stone floors in shelters \%8.51, wood floors in shelters \%5.57, \%6.66 in rubber flooring shelter, and in earth-floored shelter foot diseases and nail deformities as $\% 46.28$ were identified. SPSS for Windows 21.0 (IBM) using Descriptive Stastistics Analysis Crosstabs method with Chi-Square test, shelter floor types (concrete, stone, wood, rubber, earth) grown cattle foot disease and were analyzed in terms of the investigation of the effects on the nail deformation. In the light of the results $\mathrm{P}<0.05$ and $\mathrm{P}<0.01$ were considered significant in terms of the range of trial data.
\end{abstract}

Keywords: Foot Diseases, Shelter Floor, Cattle.

\section{Giriş}

Tırnak hastalıklarının dünya üzerindeki tüm sığırlarda sıklıkla görüldüğü ve sığırlarda görülen topallıkların \%90'ının tırnak ve ayak hastalıklarıyla ilişkili olduğu bildirilmiştir (Weaver, 2000). Ayrıca sığırlarda topallıklar geniş ölçüde ekonomik kayıplara neden olan bir problem olarak tanımlanmaktadır (Vermuntand ve Greenough, 1996). Topalıkların bakım şartları, beslenme, yaş, genetik, canlı ağırlık, laktasyon, hayvanın özellikleri ve barınak dizaynı arasındaki etkileşim sonucunda meydana gelen multifaktöryel şartlarla karakterize olduğu ifade edilmektedir (Clarkson ve ark., 1993; Hedges ve ark., 2000). Ayrıca zemin yüzeyinin direk olarak tırnak sağlığı ve hayvanın hareketleri üzerinde etkili bir faktör olduğu vurgulanmaktadır (Albright, 1995).
Süt sığırlarında çevresel faktörlerin özellikle de ahır zemin yapısının topalıkların oluşmasında belirleyici bir faktör olduğu bildirilmektedir (Cook ve ark., 2004). Kötü ahır zeminleri sığırlar da eksternal travmalar, laminitis, solea hemorajileri, solea ülseri, beyaz çizgi ayrılmaları, ökçe ezilmesi, tırnak çatlağı gibi lezyonları tetikleyici faktörlerden birisi olarak kabul edilmektedir (Chesterton, 1989; Cookand Nordlund, 2009). Beton zeminlerin sert oluşu ve aşındırıcı etkisi tırnağın boynuz kısmını daha hızlı aşınmasına yol açar (Vermuntand ve Greenough, 1995). Buna bağlı olarak da ayak lezyonları ve topallıklar ortaya çıkmaktadır (Bergsten ve Frank, 1996; Van Amstel ve ark., 2004). Yumuşak malzeme kullanılan ahır zeminleri ayaklar üzerine uygulanan basıncı azaltır (Hinterhofer ve ark., 2005). Bazı araştırmacılar ayak lezyonlarını 
azaltmak için saman altlıklı ahırları ve kauçuk paspas kullanımını önermektedirler (Benz, 2002; Somers ve ark., 2003).

Yapılan çalışmalar yumuşak zeminli ahırlarda sert zeminli ahırlara göre daha az tırnak lezyonlarının meydana geldiğini göstermiştir. Son yıllarda süt sığırcılığı ahırlarında kauçuk zemin kullanımı sert zeminlere alternatif olarak incelenmektedir (Bell ve Huxley, 2009; Vanegas ve ark., 2006). Ancak bazı araştırmacılar kauçuk zeminlerin ayak sağlığı üzerine olumsuz etkiye sahip olduğunu bildirmişlerdir (Boyle ve ark., 2007; Krebs ve ark., 2011; Kremer ve ark., 2007). Ahır zemininde ahşap yapı kullanımı ayaklar üzerinde daha fazla basınca neden olabilir (Hinterhofer ve ark., 2006). Bazı araştırmacılarda ahşap zeminlerin zemindeki gübrenin nemini azalttığını ve sığırların toynaklarında kurumaya neden olduğunu vurgulamışlardır (Telezhenko ve Bergsten, 2005). Yine yapılan araştırmalarda barınak zemininde kum kullanılan sürülerin ayak hastalıklarının prevalansında önemli ölçüde azalma olduğunu gözlemlemiştir (Cook, 2003).

$\mathrm{Bu}$ çalışmada, Muş yöresinde farklı zeminlere sahip ahırlar da barındırılan sığırlarda meydana gelen ayak hastalıkları ve tırnak deformiteleri üzerine barınak zeminlerinin etkilerinin ortaya konulması amaçlanmıştır.

\section{Materyal ve Metot}

Çalışmanın materyalini; hayvan popülasyonunun yoğun olduğu Türkiye-Muş yöresinin farklı bölgelerindeki 81 ahır ve değişik yaş, ırk, cinsiyet ve ağırlıkta toplam 1292 baş sığır oluşturdu. incelenen bu ahırların zeminlerinin beton zemin ( $n=426$ sığır), taş zemin ( $n=110$ sığır), tahta zemin ( $n=72$ sığır), kauçuk zemin ( $n=86$ sığır), toprak zemin ( $n=598$ sığır) olduğu tespit edilmiştir.

Bu 81 ahırın barınak şartlarının uygunluğu, ahırların zemin yapısı incelendi. Hayvan sahiplerinden sığırlarda ayak hastalıklarının ve tırnak deformitelerinin görülme sıklığına yönelik anemnez alındı. Hayvanlar ayak hastalıkları yönünden ayakta dururken ve yürütülürken muayene edildi. Ayak ve tırnak yapısı incelenerek hayvanın cüssesine uygunluğu, tırnak deformasyonları, ökçe ve taban bölgesindeki bozukluklar, interdijital bölge hastalıkları ve corona bölgesindeki bozuklukların varlığı araştırıldı. Elde edilen tüm veriler kullanılmak üzere kayıt altına alındı. Çalışma sonunda tutulan veri kayıtları daha sorasında kullanılmak üzere sürü gözlem kayıt formlarına işlenerek arşivlendi. Tutulan kayıtlar değerlendirilmek üzere istatistik metotlarından SPSS for Windows 21.0 (IBM) Descriptive Stastistics Analysis Crosstabs metoduyla Chi-Square testi kullanılarak, barınak zemin tiplerinin (beton, taş, tahta, kauçuk, toprak) yetiştirilen sığırların ayak hastalıkları ve tırnak deformasyonları üzerine olan etkilerinin araştırılması yönünden analizi yapıldı. Ulaşılan sonuçların ışığı altında $\mathrm{P}<0.05$ ve $\mathrm{P}<0.01$ aralıkları çalışma verileri açısından anlamlı olarak kabul edildi.

\section{Bulgular}

Çalışmada incelenen ahırlarda havalandırma sistemlerinin yetersiz olduğu (\%18.51) veya hiç bulunmadığı (\%13.58); buna bağlı olarak da barınak ortamında yoğun bir amonyak ve gaita kokusunun varlığı tespit edildi. Araştırmanın yapıldığı işletmelere ait barınakların zeminlerinin beton zemin (\%20.99), taş zemin (\%11.11), tahta zemin (\%9.88), kauçuk zemin (\%2.46), toprak zemin (\%55.56) olduğu tespit edilmiştir. Ayrıca barınak zeminlerinde dışkı ve idrar kanallarının yapılmaması (\%11.11) veya yetersiz / uygunsuz yapılması (\%20.99) nedeniyle, idrar ve dışkının barınak zemininde biriktiği, hayvanların özellikle arka ayaklarının gaita ve idrar birikintileri içerisinde kaldığı belirlendi. Özellikle toprak ve tahta zeminli barınaklarda bu olguya sıkça rastlanıldı. Yine toprak ve beton zeminli barınakların zeminlerinde oluşan çukurlarda idrar ve gaita birikintilerine rastlanıp bunların temizlemede problem oluşturduğu izlendi. Çalışmada ahır zeminlerine göre tırnaklarda deformite ve ayak hastalıkları oranları beton zeminli barınaklarda \%32.97, taş zeminli barınaklarda \%8.51, tahta zeminli barınaklarda \%5.57, kauçuk zeminli barınaklarda \%6.66, toprak zeminli barınaklarda ise $\% 46.28$ olarak tespit edilmiştir.

Sığırların barınak zeminlerine göre tırnaklarında görülen deforme tırnak yapılarının oranları; beton zeminli barınaklarda barındırılan hayvanlarda \%1.88 küt tırnak, \%1.64 makas tırnak, \%3.52 sivri tırnak, \%1.41 ayrık tırnak, \%1.41 yayvan ve dolgun tırnak, \%1.88 burulmuş tırnak olarak saptanmıştır. Taş zeminli barınaklarda ise; \%3.64 küt tırnak, \%2.73 makas tırnak, \%7.27 sivri tırnak, \%4.55 ayrık tırnak, \%3.64 yayvan ve dolgun tırnak, \%3.64 burulmuş tırnak olarak gözlemlenmiştir. Tahta zeminli barınaklarda bu oranlar; \%2.78 küt tırnak, \%5.56 makas tırnak, \%6.94 sivri tırnak, \%2.78 yayvan ve dolgun tırnak, \%5.66 burulmuş tırnak olarak bulunmuş, ayrık tırnak olgusuna ise rastlanmamıştır. Kauçuk zeminli barınaklarda; \%1.16 oranında küt tırnak olgusu saptanmış, diğer 
tırnak deformiteleri gözlemlenmemiştir. Toprak zeminli barınaklarda ise; \%1.84 küt tırnak, \%3.55 makas tırnak, \%6.35 sivri tırnak, \%3.68 ayrık tırnak, \%3.01 yayvan ve dolgun tırnak, \%3.17 burulmuş tırnak saptanmıştır. Yapılan çalışmada ahır zeminlerine göre tırnak deformitelerine ilişkin veriler Tablo 1 'de, ayak hastalıklarına ilişkin veriler ise Tablo 2'de gösterilmiştir. Farklı ahır zemini tiplerinin tırnak deformasyonları üzerine olan etkisinin araştırıldığı bu çalışmada; saptanan verinin $\mathrm{P}<0.0019$ olarak bulunması, ahır zemin tipleri ile tırnak deformasyonları arasında anlamlı bir ilişkinin olacağı kanısına varılmıştır.

Tablo 1. Barınak zeminlerine göre sığırların ayaklarında görülen tırnak deformasyonlarının dağılımı

\begin{tabular}{|c|c|c|c|c|c|c|c|c|}
\hline \multirow[b]{2}{*}{ Barınak Zemini Tipleri } & \multicolumn{8}{|c|}{ Deforme Tırnak Yapıları } \\
\hline & Küt Tırnak & $\begin{array}{l}\text { Makas } \\
\text { Tırnak }\end{array}$ & $\begin{array}{c}\text { Sivri } \\
\text { Tırnak }\end{array}$ & $\begin{array}{c}\text { Ayrık } \\
\text { Tırnak }\end{array}$ & $\begin{array}{c}\text { Yayvan ve } \\
\text { Dolgun Tirnak }\end{array}$ & $\begin{array}{c}\text { Burulmuş } \\
\text { Tırnak }\end{array}$ & Deformasyonsuz & Toplam \\
\hline \multicolumn{9}{|l|}{ Beton } \\
\hline Hayvan Sayısı (adet) & 8 & 7 & 15 & 6 & 6 & 8 & 376 & 426 \\
\hline Barınak Zemini (\%) & 1.88 & 1.64 & 3.52 & 1.41 & 1.41 & 1.88 & 88.26 & 100.00 \\
\hline Deforme Tırnak Yapıları (\%) & 30.77 & 18.92 & 22.73 & 18.18 & 20.00 & 19.51 & 35.51 & 32.97 \\
\hline \multicolumn{9}{|l|}{ Taş } \\
\hline Hayvan Sayısı (adet) & 4 & 3 & 8 & 5 & 4 & 4 & 82 & 110 \\
\hline Barınak Zemini (\%) & 3.64 & 2.73 & 7.27 & 4.55 & 3.64 & 3.64 & 74.55 & 100.00 \\
\hline Deforme Tırnak Yapıları (\%) & 15.38 & 8.11 & 12.12 & 15.15 & 13.33 & 9.76 & 7.74 & 8.51 \\
\hline \multicolumn{9}{|l|}{ Tahta } \\
\hline Hayvan Sayısı (adet) & 2 & 4 & 5 & 0 & 2 & 4 & 55 & 72 \\
\hline Barınak Zemini (\%) & 2.78 & 5.56 & 6.94 & 0.00 & 2.78 & 5.66 & 76.39 & 100.00 \\
\hline Deforme Tırnak Yapıları (\%) & 7.69 & 10.81 & 7.58 & 0.00 & 6.67 & 9.76 & 5.19 & 5.57 \\
\hline \multicolumn{9}{|l|}{ Kauçuk } \\
\hline Hayvan Sayısı (adet) & 1 & 0 & 0 & 0 & 0 & 0 & 85 & 86 \\
\hline Barınak Zemini (\%) & 1.16 & 0.00 & 0.00 & 0.00 & 0.00 & 0.00 & 98.84 & 100.00 \\
\hline Deforme Tırnak Yapıları (\%) & 3.85 & 0.00 & 0.00 & 0.00 & 0.00 & 0.00 & 8.03 & 6.66 \\
\hline \multicolumn{9}{|l|}{ Toprak } \\
\hline & 11 & 23 & 38 & 22 & 18 & 25 & 461 & 598 \\
\hline Barınak Zemini (\%) & 1.84 & 3.85 & 6.35 & 3.68 & 3.01 & 4.18 & 77.09 & 100.00 \\
\hline Deforme Tırnak Yapıları (\%) & 42.31 & 62.16 & 57.58 & 66.67 & 60.00 & 60.98 & 43.53 & 46.28 \\
\hline \multicolumn{9}{|l|}{ Toplam } \\
\hline Hayvan Sayısı (adet) & 26 & 37 & 66 & 33 & 30 & 41 & 1059 & 1292 \\
\hline Barınak Zemini (\%) & 2.01 & 2.94 & 5.11 & 2.55 & 2.32 & 3.17 & 81.97 & 100.00 \\
\hline Deforme Tırnak Yapıları (\%) & 100.00 & 100.00 & 100.00 & 100.00 & 100.00 & 100.00 & 100.00 & 100.00 \\
\hline
\end{tabular}

Tablo 2. Barınak zeminlerine göre sığırların ayaklarında görülen ayak hastalıklarının dağılımı

\begin{tabular}{|c|c|c|c|c|c|c|c|c|c|c|}
\hline \multirow[b]{2}{*}{ Barınak zemin tipleri } & \multicolumn{10}{|c|}{ Hastalıklar } \\
\hline & $\begin{array}{c}\text { Tırnak } \\
\text { erezyonu }\end{array}$ & $\begin{array}{c}\text { Ökçe } \\
\text { apsesi }\end{array}$ & $\begin{array}{l}\text { İnterdigital } \\
\text { hiperplazi }\end{array}$ & $\begin{array}{l}\text { Interdigital } \\
\text { flegmon }\end{array}$ & $\begin{array}{l}\text { Pododermatitis } \\
\text { aseptica diffuza d }\end{array}$ & $\begin{array}{c}\text { Digital } \\
\text { dermatitis }\end{array}$ & $\begin{array}{c}\text { Beyaz çizgi } \\
\text { hastalığı }\end{array}$ & $\begin{array}{l}\text { Ökçe ve } \\
\text { taban eziği }\end{array}$ & i Sağlıklı & Toplam \\
\hline \multicolumn{11}{|l|}{ Beton } \\
\hline Hayvan Sayısı (adet) & 9 & 4 & 3 & 2 & 8 & 3 & 5 & 7 & 385 & 426 \\
\hline Barınak Zemini (\%) & 2.11 & 0.94 & 0.7 & 0.47 & 1.88 & 0.70 & 1.17 & 1.64 & 90.38 & 100.00 \\
\hline Hastalıklar (\%) & 26.47 & 17.39 & 25.00 & 11.76 & 36.36 & 25.00 & 20.00 & 17.95 & 34.75 & 32.97 \\
\hline \multicolumn{11}{|l|}{ Taş } \\
\hline Hayvan Sayısı (adet) & 1 & 3 & 2 & 2 & 1 & 1 & 4 & 5 & 91 & 110 \\
\hline Barınak Zemini (\%) & 0.91 & 2.73 & 1.82 & 1.82 & 0.08 & 0.08 & 3.64 & 4.55 & 82.73 & 100.00 \\
\hline Hastalıklar (\%) & 2.94 & 13.04 & 16.67 & 11.76 & 4.55 & 8.33 & 16.00 & 12.82 & 8.21 & 8.51 \\
\hline \multicolumn{11}{|l|}{ Tahta } \\
\hline Hayvan Sayısı (adet) & 2 & 1 & 1 & 2 & 2 & 2 & 1 & 2 & 59 & 72 \\
\hline Barınak Zemini (\%) & 2.78 & 1.39 & 1.39 & 2.78 & 2.78 & 2.78 & 1.39 & 2.78 & 81.94 & 100.00 \\
\hline Hastalıklar (\%) & 5.88 & 4.39 & 8.33 & 11.76 & 9.09 & 16.67 & 4.00 & 5.13 & 5.32 & 5.57 \\
\hline \multicolumn{11}{|l|}{ Kauçuk } \\
\hline Hayvan Sayısı (adet) & 0 & 0 & 0 & 0 & 1 & 1 & 0 & 0 & 84 & 86 \\
\hline Barınak Zemini (\%) & 0.00 & 0.00 & 0.00 & 0.00 & 1.16 & 1.16 & 0.00 & 0.00 & 97.67 & 100.00 \\
\hline Hastalıklar (\%) & 0.00 & 0.00 & 0.00 & 0.00 & 4.55 & 8.33 & 0.00 & 0.00 & 7.58 & 6.66 \\
\hline \multicolumn{11}{|l|}{ Toprak } \\
\hline Hayvan Sayısı (adet) & 22 & 15 & 6 & 11 & 10 & 5 & 15 & 25 & 489 & 598 \\
\hline Barınak Zemini (\%) & 3.68 & 2.51 & 1.00 & 1.84 & 1.67 & 0.84 & 2.51 & 4.18 & 81.77 & 100.00 \\
\hline Hastalıklar (\%) & 64.71 & 65.22 & 50.00 & 64.71 & 45.45 & 41.67 & 60.00 & 64.10 & 44.13 & 46.28 \\
\hline \multicolumn{11}{|l|}{ Toplam } \\
\hline Hayvan Sayısı (adet) & 34 & 23 & 12 & 17 & 22 & 12 & 25 & 39 & 1108 & 1292 \\
\hline Barınak Zemini (\%) & 2.63 & 1.78 & 0.93 & 1.32 & 1.70 & 0.93 & 1.93 & 3.02 & 85.76 & 100.00 \\
\hline Hastalıklar (\%) & 100.00 & 100.00 & 100.00 & 100.00 & 100.00 & 100.00 & 100.00 & 100.00 & 100.00 & 100.00 \\
\hline
\end{tabular}


Yapılan çalışmada sığırlar, barınak zeminlerine göre ayak hastalıkları yönünden incelendiğinde; beton zeminli barınaklarda ökçe erezyonu $\% 2.11$, ökçe apsesi \%0.94, interdijital hiperplazi $\% 0.70$, interdijital flegmon $\% 0.47$, Pododermatitis aseptica diffuza \%1.88, digital dermatitis $\% 0.70$, beyaz çizgi hastalığı \%1.17, ökçe ve taban eziği \%1.64 oranında olduğu tespit edilmiştir. Taş zeminli barınaklarda; ökçe erezyonu \%0.91, ökçe apsesi \%2.73, interdijital hiperplazi \%1.82, interdijital flegmon \%1.82, Pododermatitis aseptica diffuza $\% 0.08$, digital dermatitis $\% 0.08$, beyaz çizgi hastalığı \%3.64, ökçe ve taban eziği \%4.55 olarak saptanmıştır. Tahta zeminli barınaklarda; ökçe erezyonu \%2.78, ökçe apsesi $\% 1.39$, interdijital hiperplazi \%1.39, interdijital flegmon \%2.78, pododermatitis aseptica diffuza $\% 2.78$, digital dermatitis \%2.78, beyaz çizgi hastalığı \%1.39, ökçe ve taban eziği \%2.78 olarak gözlemlenmiştir. Kauçuk zeminli barınaklarda; pododermatitis aseptica diffuza \%1.16, ve digital dermatitis \%1.16 olarak bulunmuş diğer hastalıklara rastlanmamıştır. Toprak zeminli barınaklarda ise bu oranlar; ökçe erezyonu \%3.68, ökçe apsesi \%2.51, interdijital hiperplazi \%1.00, interdijital flegmon $\% 1.84$, pododermatitis aseptica diffuza \%1.67, digital dermatitis \%0.84, beyaz çizgi hastalığı \%2.51, ökçe ve taban eziği \%4.18 tespit edilmiştir. Farklı barınak zemini tiplerinin ayak hastalıkları üzerine olan etkisinin araştırıldığı bu çalışmada; saptanan verinin $\mathrm{P}<0.0052$ olarak bulunması, referans noktası çerçevesinde barınak zemin tipleri ile ayak hastalık arasında anlamlı bir ilişkinin olacağı düşündürmüştür.

\section{Tartışma ve Sonuç}

Yapılan çalışmalarda farklı barınak zemin tiplerinin ayak hastalıkları ve tırnak yapılarını etkilediği bildirilmiştir (Benz, 2002; Haufe ve ark., 2012; Kremer ve ark., 2007; Vokey ve ark., 2001). Yapılan bir başka araştırmada beton zeminli barınaklarda yetiştirilen sığırların ayaklarında görülen hastalıkların prevalansını \%19.8, toprak zeminli barınaklarda yetiştirilen sığırlarda ise \%2.9 olarak tespit etmişlerdir (Fayeand ve Lescourret, 1989). Birçok araştırmacı sert barınak zemin yüzeyinin ayak tabanında çeşitli hastalıklara yol açan etken olduğunu kabul etmiştir (Barker ve ark., 2009; Kenneth ve ark., 2004; Nordlund ve ark., 2004). Yaptığımız bu saha çalışması sonrasında, barınakların zemin tiplerine göre, sığırların ayaklarındaki deforme tırnak ve hastalık oranları beton zeminli barınaklarda \%32.97, taş zeminli barınaklarda \%8.51 olarak bulunmuştur. Bu oranlar tahta zeminli barınaklarda \%5.57 iken kauçuk zeminli barınaklarda \%6.66, toprak zeminli barınaklarda ise $\% 46.28$ olarak tespit edilmiştir. Toprak ve beton zeminli barınaklarda barındırılan hayvanlarda deforme tırnak yapılarının ve ayak hastalıklarının fazla görülme nedeni; bu zeminlerde yetiştirilen hayvanlara tırnak bakımlarının yetersiz ya da hiç yapılmaması ve sığır popülasyonun \%55.56'sının toprak, \%20.99'unun beton zemine sahip barınaklarda yetiştirilmesinin etken olabileceği düşünülmüştür.

Bazı araştırmacılar yaptıkları çalışmalarda farklı barınak zeminlerinde tutulan hayvanların tırnaklarının boyutlarında farklılıkların olduğunu buna bağlı olarak deforme tırnak yapılarının olduğunu tespit etmişlerdir (Andersson ve Lundström, 1981). Ayrıca farklı barınak zeminlerinde boynuz tırnaktaki büyüme oranlarındaki farklılık sebebiyle özellikle medial ve lateral tırnak arasında boyut farklılıklarından dolayı deforme tırnak yapılarının varlığından bahsedilmektedir (Tranterand ve Morris, 1992). Bu çalışmada; ahır zeminlerine göre sığırların tırnaklarında görülen deforme tırnak yapılarının oranları; beton zeminli barınaklarda barındırılan hayvanlarda \%1.88 küt tırnak, \%1.64 makas tırnak, \%3.52 sivri tırnak, \%1.41 ayrık tırnak, \%1.41 yayvan ve dolgun tırnak, \%1.88 burulmuş tırnak olarak saptanmıştır. Taş zeminli barınaklarda ise; \%3.64 küt tırnak, \%2.73 makas tırnak, \%7.27 sivri tırnak, \%4.55 ayrık tırnak, \%3.64 yayvan ve dolgun tırnak, \%3.64 burulmuş tırnak olarak gözlemlenmiştir. Tahta zeminli barınaklarda bu oranlar; \%2.78 küt tırnak, \%5.56 makas tırnak, \%6.94 sivri tırnak, \%2.78 yayvan ve dolgun tırnak, \%5.66 burulmuş tırnak olarak bulunmuş, ayrık tırnak olgusuna ise rastlanmamıştır. Kauçuk zeminli barınaklarda; \%1.16 oranında küt tırnak olgusu saptanmış, diğer tırnak deformiteleri gözlemlenmemiştir. Toprak zeminli barınaklarda ise; \%1.84 küt tırnak, \%3.55 makas tırnak, \%6.35 sivri tırnak, \%3.68 ayrık tırnak, \%3.01 yayvan ve dolgun tırnak, \%3.17 burulmuş tırnak saptanmıştır. Tırnak deformitelerinin tespit edildiği barınaklarda barınak zeminin kirli olmasının, hayvanların tırnak bakımlarının ve kesimlerinin düzenli yapılmamasının, hayvanların uzun süre barınak ortamında tutularak dışarı çıkarılıp gezdirilmemesinin etken olabileceği düşünüldü.

Bazı araştırmacılar ahşap zeminli barınaklarda daha fazla burulmuş tırnak olgularına rastlandığını ifade etmiştir (Fjeldaas ve ark., 2010). Bazı araştırmacılar yaptıkları çalışmada barınak yüzeyi ile tırnak arasında bir ilişkinin olduğunu, sert ve aşındırıcı özelliğe sahip beton zeminlerin tırnağın boynuz tabakasını aşındırdığını ifade 
etmişlerdir (Vermunt ve Greenough, 1995). Bazı araştırmacılara beton zeminli barınaklardaki hayvanlarda solea hemoraji, solea ülseri, beyaz çizgi hastalığı gibi hastalıkların toprak zeminli barınaklarda barındırılanlara oranla daha fazla görüldüğünü belirtmişlerdir (Franck ve ark., 2008; Frankena ve ark., 1992).

Yapılan bir araştırmada ahşap, beton, kauçuk gibi farklı barınak zemin sistemlerinde tutulan sığırların tırnaklarında ökçe erezyonu, interdigital dermatit, solea hemorajisi, digital dermatitis, interdigital hiperplazi gibi ayak hastalıklarının görüldüğü bildirilmiştir (Somers ve ark., 2003). Fjeldaas ve ark. (2010) slatted concrete, solid concrete veya solid rubber zeminli barınaklarda barındırılan sığırların ayaklarındaki hastalıklar (dermatitis, white line disease, sole hemorrhage) üzerine yaptığı çalışmada dermatitis vakalarını slatted concrete zeminlilerde daha sık görüldüğünü, ancak double sole olgularının solid concrete'de daha fazla tespit edildiğini bildirmişlerdir. Araştırmacılar yaptıkları çalışmalarda kauçuk ve beton zeminli barınaklardaki sığırların ayaklarında solea hemorajilerine ve beyaz çizgi hastalığına rastlandığını bildirmişlerdir (Cook ve Nordlund, 2009; Kremer ve ark., 2007; Ouweltjes ve ark., 2009). Barınak zeminin ayak hastalıkları üzerine etkisi ile ilgili yapılan çalışmalarda beton zeminli barınaklardaki sığırların tırnak lezyonu oranlarının, kauçuk ve kum zeminli barınaklardakine kıyasla daha fazla olduğu bildirmektedirler (Boyle ve ark., 2007; Vanegas ve ark., 2006). Yapılan bir çalışmada beton zeminlerin ve kötü barınak şartlarının ayak hastalıklarına (solea ulseri, çift tabanlılık, beyaz çizgi lezyonları, dermatitis) neden olduğunu bildirmektedir (Manske, 2002). Yaptığımız saha çalışmasında barınak zeminlerine göre ayak hastalıkları incelendiğinde beton zeminli barınaklarda; ökçe erezyonu \%2.11, ökçe apsesi \%0.94, interdijital hiperplazi \%0.70, interdijital flegmon \%0.47, pododermatitis aseptica diffuza \%1.88, digital dermatitis \%0.70, beyaz çizgi hastalığı \%1.17, ökçe ve taban eziğine \%1.64 oranında rastlandığı tespit edilmiştir. Taş zeminli barınaklarda; ökçe erezyonu \%0.91, ökçe apsesi \%2.73, interdijital hiperplazi \%1.82, interdijital flegmon \%1.82, pododermatitis aseptica diffuza $\% 0.08$, digital dermatitis \%0.08, beyaz çizgi hastalığı \%3.64, ökçe ve taban eziği \%4.55 olarak saptanmıştır. Tahta zeminli barınaklarda; ökçe erezyonu $\% 2.78$, ökçe apsesi \%1.39, interdijital hiperplazi $\% 1.39$, interdijital flegmon $\% 2.78$, pododermatitis aseptica diffuza \%2.78, digital dermatitis $\% 2.78$, beyaz çizgi hastalığı \%1.39, ökçe ve taban eziği \%2.78 oranında gözlemlenmiştir. Kauçuk zeminli barınaklarda; pododermatitis aseptica diffuza \%1.16, ve digital dermatitis \%1.16 olarak bulunmuş diğer hastalıklara rastlanmamıştır. Toprak zeminli barınaklarda ise bu oranlar; ökçe erezyonu \%3.68, ökçe apsesi \%2.51, interdijital hiperplazi \%1.00, interdijital flegmon \%1.84, pododermatitis aseptica diffuza \%1.67, digital dermatitis \%0.84, beyaz çizgi hastalığı \%2.51, ökçe ve taban eziğine \%4.18 olarak tespit edildi.

Ayak hastalıklarının saptandığı barınakların zeminlerinde yeterince hijyen kurallarına dikkat edilmemesi, idrar ve dışkı kanallarının yeterince olmaması, barınak zemininde altlık kullanılmaması, ayak banyosu ve tırnak bakımı gibi uygulamaların rutin olarak yapılmamasının etken olabileceği düşünüldü. Muş yöresinde yürütülen bu çalışmada, sığırlarda farklı zemin yapılarının tırnak deformasyonları ve ayak hastalıkları üzerine etkilerinin araştırılması amaçlandı. Çalışmada elde edilen veriler doğrultusunda ahır zeminlerinin yapısal özellikleri sığırlarda ayak-tırnak lezyonlarında rol oynadığı düşünülmektedir.

\section{Kaynaklar}

Albright JC, 1995: Flooring in dairy cattle facilities, in Proc. Int. Conf. Anim. Behav. Design. Livest. Poult. Syst., Indianapolis, IN, 168-182.

Andersson L, Lundstrm K, 1981: Their fluence of breed, age, body weight and season on digital diseases and hoof size in dairy cows. J Vet Med A, 28, 141-151.

Barker ZE, Amory JR, Wright JL, Mason SA, Blowey RW, Green LE, 2009: Risk factors forin creased rates of sole ulcers, white line disease and digital dermatitis in dairy cattle from twenty-seven farms in England and Wales. J Dairy Sci, 92, 1971-1978.

Bell NJ, Huxley JN, 2009: The use of rubber flor matting on dairy units: a critical review. Cat Pract, 17, 142147.

Bergsten C, Frank B, 1996: Sole haemorrhages in tied primiparous cows as an indicator of periparturient laminitis: effects of diet, flooring and season. Acta Veterinaria Scandinavica, 37, 383-394.

Benz B, 2002: Elastische Belägefür spaltenböden in Liegebox enlaufställen, PhD Thesis, Universität Hohenheim, Hohenheim, Germany

Boyle L, Mee J, Kiernan P, 2007: The effect of rubber versus concrete passage ways in cubicle housing on claw health and reproduction of pluriparous dairy cows. Appl Anim Behav Sci, 106, 1-12.

Chesterton RN, 1989: Examination and control of lameness in dairy herds. N Z Vet J, 37, 133-134.

Clarkson MJ, Downham DY, Faull WB, Hughes JW, Manson FJ, Merrit JD, Murray RD, Russell WB, Sutherst JE, Ward WR, 1993: An epidemiological study to determine the risk factors of lameness in dairy cows, CSA 1379, Univ. Liverpool, United Kingdom. 
Cook NB, 2003: Prevalence of lameness among dairy cattle in Wisconsin as a function of housing type and stall surface. JAVMA, 223, 1324-1328.

Cook NB, Nordlund KV, Oetzel GR, 2004: Environmental influences of claw horn lesions associated with laminitis and subacute ruminal acidosis in dairy cows. J Dairy Sci, 87(E.Suppl.), E36-E46.

Cook NB, Nordlund KV, 2009: The influence of the environment on dairy cow behavior, claw health and herd lameness Dynamics. Vet J, 179, 360-369.

Faye B, Lescourret F, 1989: Environmental factors associated with lameness in dairy cattle. Preventative Veterinary Medicine, 7, 267-287.

Fjeldaas T, Sogstad ÅM, Østerås O, 2010: Locomotion and claw disorders in Norwegian dairy cows housed in free stalls with slatted concrete, solid concrete, or solid rubber flooring in the alleys. I Dairy Sci, 94, 1243-1255.

Franck A,Verhegghe B, Belie N, 2008: The effect of concrete floor roughness on bovine claws using finite element analysis. J Dairy Sci, 91, 182-192.

Frankena K,Van Keulen KAS, Noordhuizen JP, Noordhuizen-Stassen EN, Gundelach J, De Jong DJ, Saedt I, 1992: A cross sectional study into prevalence and risk factors of digital haemorrhages in female dairy calves. Preventive Veterinary Medicine, 14, 1-12.

Helge CHL, Gygaxa B, Wechsler M, Stauffacher K, 2012: Influence of floor surface and access to pasture on claw health in dairy cows kept in cubicle housing systems. Preventive Veterinary Medicine, 105, 8592.

Hedges VJ, Blowey RJ, Packington AJ, O'Callaghan CJ, Green LE, 2001: A longitudinal field trial of the effect of biotin on lameness in dairy cows. J Dairy Sci, 84, 1969-1975.

Hinterhofer C, Ferguson JC, Apprich V, Haider H, Stanek C, 2006: Slatted floors and solid floors: Stress and strain on the bovine hoof capsule analyzed in finite element analysis. J Dairy Sci, 89, 155-162.

Kenneth V, Nigel B, Garrett R, 2004: Investigation Strategies for Laminitis Problem Herds. J Dairy Sci, 87(E. Suppl.), E27-E35.

Krebs N, Berry SL, Tucker CB, 2011: Restless behavior increases over time, but not with compressibility of the flooring surface, during forced standing at the feed bunk. J Dairy Sci, 94, 97-105.
Kremer PV, Nueske S, Scholz AM, Foerster M, 2007: Comparison of claw health and milk yield in dairy cows on elasticor concrete flooring. J Dairy Sci, 90, 4603-4611.

Manske T, 2002: Hoof lesions and lameness in Swedish dairy cattle; prevalence, risk factors, effects of claw trimming and consequences for productivity, Animal Environment and Health. Skara: Swedish Univ Agr (SLU).

Nordlund KV, Cook NB, Oetzel GR, 2004: Investigation strategies for laminitis problem herds. J Dairy Sci 87, 27-35.

Ouweltjes W, Holzhauer M, Van der Tol PP, Van der Werf J, 2009: Effects of two trimming methods of dairy cattle on concrete and rubber-covered slatted floors. J Dairy Sci, 92, 960-971.

Somers JG, Frankena K, Noordhuizen-Stassen EN, Metz $\mathrm{JH}$, 2003: Prevalence of claw disorders in Dutch dairy cow sex posed to several flor systems. J Dairy Sci, 86, 2082-2093.

Telezhenko E, Bergsten C, 2005: Influence of floor type on the locomotion of dairy cows. Aplied Animal Behaviour Science, 93, 183-197.

Tranter WT, Morris RS, 1992: Hoof growth and wear in pasture-fed dairy cattle. $N Z$ Vet J, 40, 89-96.

Van Amstel SR, Shearer JK, Palin FL, 2004: Moisture content, thickness, and lesions of sole horn associated with thin soles in dairy cattle. J Dairy Sci, 87, 757-763.

Vanegas J, Overton M, Berry SL, Sischo WM, 2006: Effect of rubber flooring on claw health in lactating dairy cows housed in free-stall barns. J Dairy Sci, 89, 42514258.

Vermunt JJ, Greenough PR, 1996: Claw conformation of dairy heifers in two management systems. $\mathrm{Br}$ Vet $\mathrm{J}$, 152, 321-331.

Vermunt JJ, Greenough PR, 1995: Structural characteristics of the bovine claw: Horn growth and wear, horn hardness and claw conformation. $\mathrm{Br}$ Vet J, 151, 157-180.

Vokey FJ, Guard CL, Erband HE, Galton DM, 2001: Effect of alley stall surface on indices of claw and leg health in dairy cattle housed in free stall barn. $J$ Dairy Sci, 84, 2686-2699.

Weaver AD, 2000: Lameness in the Health of Dairy Cattle. A.H. Andrews, ed. Blackwell Science, Oxford, United Kingdom, 149-202.

*Yazışma Adresi: Eren POLAT

Fırat Üniversitesi, Veteriner Fakültesi,

Cerrahi Anabilim Dalı, Elazığ, Türkiye.

e-mail: erenpolat@firat.edu.tr 